H. LANGKAMMER, OFM, Maryja w Nowym Testamencie, Gorzowskie Wyd. Diecezjalne, Gorzów Wlkp 1991, ss. 204.

Książka ta — według zamysłu Autora (Wstęp) - pomyślana została jako mariologia, a równocześnie jako III część jego dwutomowej edycji Teologia Nowego Testamentu. Jest to mariologia biblijna par excellence. Praca została podzielona na sześć rozdziałów: 1. Maryja, Matka Zbawiciela; 2. Dziewicza Służebnica Pańska; 3. Matka zawierzenia; 4. Matka boleściwa; 5. Maryja u progu Nowego Przymierza; 6. Maryja znakiem eschatologicznym. Dwa apendyksy obejmują, ,aspekty mariologiczne” ST: Rdz 3,14n; Iz 7,14n, Mądrość Boża oraz użycie tekstów biblijnych w encyklice Jana Pawla II Redemptoris Mater. Popularny sposób ujęcia, nie przeładowanie techniką egzegetyczną, zasadnicze odniesienia do literatury przedmiotu czynią z tej książki pożyteczny instrument konsultacji w pracy duszpasterskiej nad rozwojem i właściwym ustawieniem kultu maryjnego w Polsce, co postuluje tekst roboczy II Polskiego Synodu Plenarnego „Nauka o Kościele i o miejscu Matki Bożej w Kościele".

Kraków

KS. JERZY CHMIEL

C. BISSOLI (red.), Giovani e Bibbia. Per una lettura esistenziale della Bibbia nei gruppi giovanili, Elle Di Ci Leumann, Torino 1991, ss. 267.

Książka zrodziła się z serii artykułów wcześniej publikowanych na łamach czasopisma „Note di Pastorale giovanile”, które ukazuje się dzięki Salezjańskiemu Centrum Duszpasterstwa Młodzieżowego przy Papieskim Uniwersytecie Salezjańskim w Rzymie. Składa się z pięciu części. W pierwszej wskazuje się na niektóre wzorce (wspólnota zakonna, Rewizja życia, ,comunità di base”, neokatechumenat), dokonując nad nimi krytycznej refleksji (C. Bissoli). W drugiej mamy lekturę Biblii w perspektywie hermeneutyki (A. Rizz) z uwypukleniem problemów, które się z nią łączą (G. Barbaglio) oraz ze zwróceniem uwagi na dwa uzupełniające aspekty podejścia do Biblii, które muszą charakteryzować lekturę Pisma św. w środowisku mlodzieżowym: aspekt mądrościowy (C. Di Sante) i aspekt pedagogiczno-religijny (C. Bissoli).

Trzecia część zwraca uwagę na wymogi, konieczne dla poprawnej i owocnej lektury Biblii: być ubogim (E. Bianchi); czytać Biblię w Kościele (R. Fabris); postawa mądrościowa (A. Bonora); uczynić z lektury Biblii ,wydarzenie opowiadane” (C. Molari); grupa jako „miejsce hermeneutyczne” (M. Polo). Czwarta część (C. Bissoli, J. Vecchi, C. Buzzetti, R. Tonelli) jest refleksją bezpośrednio pedagogiczno-duszpasterską, zaś piąta jest pewnego rodzaju „dossier”, natury technicznej, odnoszącym się do różnych kierunków współczesnej hermeneutyki biblijnej: lektura historyczno-krytyczna, socjopolityczna, psychologiczna, duchowa oraz strukturalizm i semiotyka.

Kraków

KS. RYSZARD KEMPIAK SDB

KS. M. BEDNARZ, Zastuchani w stowo Pana. Materiały na Niedzielę Biblijną, Wyd. Biblos, Tarnów 1991, ss. 183.

Książka dzieli się na dwie części: część teoretyczną i praktyczną. Część teoretyczna zatytulowana „Wprowadzenie metodyczne" przynosi uzasadnienie potrzeby niedzieli biblijnej, którą propagował słynny liturgista o. Pius Parsch. Zostały podane podstawowe informacje, jak zorganizować taką niedzielę (zachęta biskupa, katecheza, nabożeństwo słowa Bożego, uroczysta intronizacja Biblii, konkursy biblijne, wystawy Biblii i różnych pomocy itd). Zostały omówione dokładniej takie formy, jak nabożeństwo słowa 
Bożego, godzina biblijna, spotkania biblijne (metoda Martiniego i Mestersa). Część praktyczna zawiera materiały do wykorzystania w czasie różnych nabożeństw i spotkań.

Książka została napisana w oparciu o doświadczenie duszpasterkie diecezji tarnowskiej, gdzie na zarządzenie nowego biskupa została w styczniu $1991 \mathrm{r}$. przeprowadzona w całej diecezji niedziela biblijna. Książka może służyć jako pomoc w przeprowadzeniu niedzieli biblijnej, tymbardziej, że tekst roboczy II Polskiego Synodu Plenarnego proponuje wprowadzenie w każdej parafii niedzieli biblijnej oraz tygodnia biblijnego (por. Biblia-Sobór-Życie, IV,3).

Kraków

KS. JERZY CHMIEL

\section{POLSKIE QUMRANICA (przegląd)}

Bez żadnej przesady i obawy o megalomanię można mówić o polskich qumranikach, czyli publikacjach w Polsce wydawanych na temat wykopalisk znad Morza Martwego (nie tylko Qumran). Inicjatorem tych edytorskich przedsięwzięć jest dr Zdzisław Jan $\mathrm{K}$ a p e r a, krakowski orientalista i edytor, organizator trzech międzynarodowych kolokwiów nt. odkryć nad Morzem Martwym, które to spotkania miały miejsce w Krakowie-Mogilanach w latach: 1987, 1989 i 1991 (zob. sprawozdania w RBL). Polska staje się w ten sposób jakby centrum badań czy spotkań kumranologicznych. Ważną rzeczą jest publikowanie w językach kongresowych, co pozwala na nawiązywanie i utrzymywanie kontaktów z całą nauką światową.

I. Została założona seria QUMRANICA MOGILANENSIA, która obejmuje dwie podserie: A. Publikacje książkowe (Pamphlets and Books) i B. biuletyn ,The Qumran Chronicle".

A. Publikacje książkowe QM:

Vol. 1. H.H. B u rg m a n ner, ,Sitz im Leben” in den Josuafluch-Texten in $4 Q 379$ 22 II und 4Q Testimonia, Kraków-Offenburg 1990, ss. 64. Autor (1914-1992), wybitny kumranolog, związany pierwotnie z tzw. szkołą marburską, a potem działający indywidualnie, uczestniczył aktywnie w mogilańskich spotkaniach kumranologicznych. W recenzowanej pracy zostały omówione dwa teksty związane z klątwą Jozuego (zob. Joz 6,26) i zachowane w dwóch odrębnych dokumentach znalezionych w Qumran. Wiąże się to z zamordowaniem machabejskiego kapłana Szymona i jego synów w r. 134 przed Chr. oraz późniejszą interpretacją tych faktów.

Vol. 3. Mogilany 1989. Papers on the Dead Sea Scrolls offered in memory of Jean Carmignac. Part II: The Teacher of Rightrousness - Literary Studies, Kraków 1991, ss. 244. Została tutaj pomieszczona część materiałów z II Międzynarodowego Kolokwium Qumranologicznego dotycząca „Nauczyciela Sprawiedliwości”, jak również inne referaty. Część II materiałów z tego mogilańskiego spotkania kumranologów w 1989 r., poświęconego pamięci wybitnego znawcy zagadnień z Qumran, ks. Jeana Carmignaca (1914-1986), znajdzie się w vol. 2 QM (w druku).

Vol. 5. H. B u rg m a n n, Die Geschichte der Essener von Qumran und „Damaskus”, Kraków-Offenburg 1990, ss. 180, ilustr. i ryc. Jest to historia esseńczyków pióra zmarłego w r. 1992 znanego kumranologa i religiologa.

B. Biuletyn „The Qumran Chronicle”, Cracow.

No. 1. August 1990. Zawiera artykuły i streszczenia (Abstracts) referatów wygłoszonych na II Międzynarodowym Kolokwium Qumranologicznym w Krakowie-Mogilanach 1989.

No. 2. Appendix „A”. December 1990. Przedruk anonimowej prepublikacji (tekst hebrajski i przekład angielski) słynnego od paru lat rękopisu Miqsat Ma'aseh ha-Torah z groty 4 Qumran (4Q MMT).

No. 2/3. December 1990/April 1991. Qumran Cave IV and MMT. Special Report, Kraków 1991, ss. 120, ilustr.

Specjalnie przygotowana przez Z.J. Kaperę praca zbiorowa omawiająca „sensacje” związane $\mathrm{z}$ rękopisem MMT (którego tekst i przekład został pomieszczony w nrze 2, 